\title{
Antidiabetic and Antilipidemic Effect of Khaya senegalensis Ethanolic Bark Extract in Alloxan Induced Diabetic Wistar Rats
}

\author{
R.U. Ukpanukpong ${ }^{1}$, J.O. Ajani ${ }^{2}$, W.A. Omang ${ }^{1}$, M.A. Adejorin ${ }^{2}$, \\ M.U. Eteng ${ }^{1}$ and E.U. Eyong ${ }^{1}$ \\ ${ }^{1}$ Department of Biochemistry, University of Calabar, Calabar-Nigeria \\ ${ }^{2}$ Department of Chemical Sciences, Biochemistry Unit, Joseph Ayo Babalola University, \\ Ikeji- Arakeji, Nigeria \\ *Corresponding author
}

\begin{tabular}{|l|}
\hline K e y w o r d s \\
Phytochemicals, \\
$\begin{array}{l}\text { Glucose level } \\
\text { Heamatological indices, } \\
\text { Lipid Profile, Hepatic } \\
\text { Serum Enzymes }\end{array}$ \\
\hline Article Info \\
\hline $\begin{array}{l}\text { Accepted: } \\
\text { 04 July 2018 } \\
\text { Available Online: } \\
\text { 10 August } 2018\end{array}$ \\
\hline
\end{tabular}

\section{Introduction}

Diabetes mellitus is a major health problem around the world and its prevalence is increasing at an alarming rate (Pavana et al., 2008). According to the World Health

\section{A B S T R A C T}

This study investigated the anti-diabetic effect of ethanolic bark extract of Khaya senegalensis in Alloxan-induced diabetic albino Wistar rats. Sixty (60) female albino rats were randomly placed into six (6) study groups of ten (10) animals designated as; nondiabetic control (NDC), diabetic control (DC), and diabetic extract treated groups (DSB1, DSB2, and DSB3) receiving varying extract concentration of $100 \mathrm{mg} / \mathrm{kg}, 200 \mathrm{mg} / \mathrm{kg}$, and $400 \mathrm{mg} / \mathrm{kg}$ body weight respectively. Animals were sacrificed after 28 days of treatment and blood was obtained for biochemical analysis. Body weight indices obtained from this study revealed a decrease $(\mathrm{p}<0.05)$ in body weight in the extract treated group when compared with non-diabetic control with an attendant increase $(\mathrm{p}<0.05)$ when compared with diabetic control. Phytochemical screening detected biologically important metabolites including phenolics and steroids while haematological parameters such as packed cell volume and haemoglobin decreased in the extract treated group when compared with the non-diabetic control but significantly increased $(\mathrm{p}<0.05)$ when compared with diabetic control. Lipid profile showed a significant decrease $(p<0.05)$ in total cholesterol and low density lipoprotein (LDL) in the extract treated group with an attendant increase when compared to the diabetic control and non-diabetic control respectively. Serum liver enzymes; alkaline phosphatase (ALP) and alanine transaminase (ALT) were increased in the extract treated group when compared to the non-diabetic control but a significant decrease $(\mathrm{p}<0.05)$ was observed in comparison with the diabetic control. In conclusion, data generated from this study show that ethanolic bark extract of Khaya senegalensis possesses antihyperglycaemic activities in alloxan induced diabetic rats. 
changes. Genetic predisposition is also a factor contributing to this menace (Wild et al., 2004). Key features in the pathogenesis of diabetes mellitus are decreased ability of insulin to stimulate glucose uptake in peripheral tissues, insulin resistance and $\beta$-cell failure (White et al., 2003).

However, management of diabetes with drugs that have minimal side effects is still a challenge in the medical field; this has led to a relentless search for improved anti-diabetic drugs. This search includes plants that are used traditionally for the treatment of diabetes (Assubaie and El-Garawany, 2004). From time immemorial, medicinal plants have been used in virtually all cultures as a source of medication in the third world countries and many of the metabolites originated from these plants have found profound use in the treatment of diseases (Falodun, 2010). It has been estimated that about $80-85 \%$ of the world population in developing nations rely on traditional system of medicine for their primary health care needs and a major part of traditional therapy involves the use of herbal drugs (Ignacimuthu et al., 2006). Before the discovery of insulin by Bantin and Best in 1922, treatment options for diabetes were basically those of traditional practice (Ribnicky et al., 2006). Among the medicinal plants used traditionally for the treatment of diabetes are Ajuga remota (Abebe et al., 2003) and Momordica charantia (Kolawole et al., 2011).

Khaya senegalensis belongs to the family Meliaceae (mahogany family), it is a popular medicinal plant widely used to treat various kinds of diseases in Nigeria and other West Africa countries. The Nupes of Niger State of Nigeria especially value the tree for its medicinal purposes. The stem bark extract is used for treating jaundice, malaria, dermatoses and hookworm infections (Gill, 1992). The ethanolic crude extract of the stem-bark of
Khaya senegalensis has been reported to possess free radical scavenging activity (Lompo et al., 2007). The seeds and leaves are also used to treat fever and headache while the root extract is used to treat mental illness, leprosy and syphilis (Maydell, 1986).

Diabetes mellitus is a disease characterized by an elevation of the level of glucose in the blood. Insulin, a hormone produced by the pancreas, controls the blood glucose level by regulating the production and storage of glucose. In diabetes there may be a decrease in the body's ability to respond to insulin or a decrease in the insulin produced by the pancreas which leads to abnormalities in the metabolism of carbohydrates, proteins and fats. The resulting hyperglycaemia may lead to acute metabolic complications including keto acidosis and in the long term contribute to chronic micro-vascular complications. Diabetes mellitus is a metabolic disorder characterized by glucose intolerance and it is a systemic disease caused by insulin supply and insulin demand imbalance (Shoback et al., 2011). The onset is from 3 years in children and 25 years in adults. The criteria for diagnosis of diabetes mellitus have been explained and include a causal plasma glucose of $11.1 \mathrm{mmol} / \mathrm{L}$ or higher, or fasting plasma glucose of $7.0 \mathrm{mmo} 1 / \mathrm{L}$ or higher. The earliest symptom of elevated blood glucose is polyuria from the osmotic diuretic of glucose but continued hyperglycemia and glycosuria may lead to thirst, hunger and weight loss (Kolawole et al., 2011).

\section{Materials and Methods}

\section{Experimental animals}

Sixty healthy female Albino Wistar rats weighing between 180-200g were obtained from the Animal House of the College of Health Sciences, Ladoke Akintola University of Technology (LAUTECH), Ogbomoso, 
Nigeria. The rats were randomly assigned on the basis of their body weight into six study groups of ten animals each. The rats were kept under normal laboratory conditions of temperature, humidity and light in secure wooden cages in the well ventilated animal house of Joseph Ayo Babalola University at normal temperature of $30^{\circ} \mathrm{C}$ to $35^{\circ} \mathrm{C}$. They were allowed free access to clean water and animal feed ad-libitum. The cages were cleaned daily and the rats were treated according to the international guidelines for the care and use of laboratory animals (NIH, 2008). The animals were allowed two weeks acclimatization and their weights were measured before treatment commenced.

\section{Chemicals}

Alloxan monohydrate, chloroform, ethanol and other chemicals were obtained from Famlab Nigeria Limited and Lixox-k chemicals, Akure respectively. Alanine transaminases (ALT), Aspartate transaminases (AST), Serum albumin were obtained from Randox Laboratories Limited, UK, and Accu Check active glucometer was purchased from Oshogbo, Osun State, Nigeria. All other chemicals used were of analytical grade. Distilled water was also used during the experimental process.

\section{Source of drug}

Insulin injection (Randox laboratories, UK) marketed by May and Baker, was obtained from a registered pharmacist in De-Shalom pharmacy, Ilesha, Osun State, Nigeria and used for the study.

\section{Plant materials and identification}

Bark of Khaya senegalensis was obtained from Ikeji-Arakeji forest. It was taken to the Department of Botany, Obafemi Awolowo University (O.A.U) for identification and authentication.

\section{Preparation of bark extract}

Bark of $K$. senegalensis was collected from Ikeji-arakeji forest, Nigeria during the month of October and dried under room temperature for four months. The dried bark of $K$. senegalensis was cut into pieces and pulverized and subsequently weighed. The powdered form was kept in an air-tight container and stored at $4^{\circ} \mathrm{C}$ pending its use for further analysis.

\section{Ethanolic extraction}

$350 \mathrm{~g}$ of the powdered extract was soaked in $650 \mathrm{ml}$ of $98 \%$ ethanol at room temperature for 72 hours after which the mixture was filtered. The filtrate was air dried at room temperature for into petri dishes and stored in sample bottles for analysis. Percentage yield was determined from the weight of the dried sample.

\section{Phytochemical screening of plant extract}

Basic phytochemical screening was the method employed to test for the presence of certain biologically active compounds in plants e.g., tannins, saponins, antraquinone, flavonoids, cardiac glycosides, steroids, phenolics, cardenolides and dienolides.

\section{Induction of diabetes}

The rats were fasted overnight and their weight and fasting blood glucose levels were recorded. They were then made diabetic by a single intraperitoneal injection of $1 \mathrm{ml}$ of alloxan monohydrate $(300 \mathrm{mg} / \mathrm{kg}$ body weight dissolved in $3 \mathrm{ml}$ distilled water). Food and water were presented to the animals 30minutes after the administration of alloxan (Nagappa et al., 2003). Three days after alloxan injection, blood samples were collected from the tail vein of the rats into the test strip of Accu check active glucometer. Animals with fasting blood glucose $\geq 200 \mathrm{mg} / \mathrm{dl}$ were isolated, 
classified diabetic, and used for the study (Kumar et al., 2005).

\section{Experimental design}

The grouping and treatment given to the rats in each groups were as follows; Group A; designated as NDC consisted of non-diabetic control rats administered $1 \mathrm{ml}$ of distilled water. Group B; designated as DC consisted of diabetic control rats without any treatment. Group C; designated as DO consisted of diabetic rats administered $1 \mathrm{ml}$ of orthodox drug (insulin). Group D: designated as DSB1 consisted of diabetic rats administered $100 \mathrm{mg} / \mathrm{kg}$ of Khaya senegalensis bark extract. Group E: designated as DSB2 consisted of diabetic rats administered $200 \mathrm{mg} / \mathrm{kg}$ of Khaya senegalensis bark extract. Group F; designated as DSB3 consisted of diabetic rats administered $4000 \mathrm{mg} / \mathrm{kg}$ of Khaya senegalensis bark extract.

\section{Sacrifice of animals and serum collection}

At the end of the experimental period the rats in each study groups were fasted overnight and sacrificed under anesthesia while blood collection was done by cardiac puncture. After sacrifice, $2-4 \mathrm{ml}$ of blood was collected from each rats and placed in specific sterile bottles (plain bottles for enzyme analysis and EDTA bottles for hematological indices). For enzyme analysis, the blood was allowed to stand for 30 minutes to clot and then centrifuged at 3000Rev for 30 minutes. The supernatant, which is the serum, was carefully decanted and was kept at $4^{0} \mathrm{C}$ for further analysis.

\section{Statistical analysis}

Data obtained were analyzed using students ' $t$ ' test and values expressed as a Mean \pm S.E.M.

Thereafter the values were considered to statistically significant at probability level of $\mathrm{p}<0.05$.

\section{Results and Discussion}

The experiment evaluated the anti-diabetic effect of Khaya senegalensis ethanolic bark extract of alloxan-induced diabetic albino Wistar rats. After induction, the rats were observed to exhibit signs and symptoms of diabetes as discussed in the literature review; these includes polyuria, polydipsia, polyphagia, weight loss and decrease in physical activities. These findings were in conformity with the hypothesis of Kolawole et al., (2011) who stated that the reduction in weight of diabetic animals is due to excessive breakdown of tissue protein which in turn is due to the increased catabolic reactions leading to muscle wasting. Furthermore, this finding was corroborated by Kamalakkannan and Prince (2006). The plant Kingdom which is one of the largest kingdoms of living organisms represents an enormous reservoir of biologically active metabolites known as Phytochemicals. Phytochemicals possessed some preventive and protective properties and in this study the presence of anthraquinone, cardiac glycoside, phenolics, steroids and cardenolides and dienolides were detected by qualitative analytic methods described by Odebiyi and Sofowora, (1978). Quantitative analysis was also carried out to determine the concentration of the phytochemicals detected during the qualitative analysis.

In this study, rats treated with various concentrations of ethanolic bark extracts $100 \mathrm{mg} / \mathrm{kg}, 200 \mathrm{mg} / \mathrm{kg}$ and $400 \mathrm{mg} / \mathrm{kg}$ showed proportional decrease in rats' body weight but at high concentrations of the extract $(400 \mathrm{mg} / \mathrm{kg})$, the animals showed a significant decrease in body weight compared to the control. This decrease indicates that bark extract of Khaya senegalensis has an adverse effect on the body weight at high concentrations as reported by Kolawole et al., (2011) who stated that reduction in the weights of rats receiving Khaya senegalensis 
extracts at very high concentrations may be due to associated toxicities resulting from metabolism of zenobiotics.

Alloxan induces diabetes by being selectively toxic to the beta-cells of the islets of Langerhans which secrets insulin, a hormone which regulates blood glucose concentration, thus, consequently resulting in the accumulation of free glucose in the blood (Suryawanshi et al., 2006). The oral administration of bark extracts of Khaya senegalensis caused a significant decrease $(\mathrm{p}<0.05)$ in the blood glucose concentration in the extract treated group when compared to the diabetic control group while a significant increase $(p<0.05)$ was observed in comparison with the non-diabetic control. The diabetic orthodox group showed a significant decrease $(\mathrm{p}<0.05)$ in blood glucose concentration when compared to diabetic control but the decrease was not significant compared to the extract treated group D1 and D2. Reduction in blood glucose level by most bioactive compounds from plants might occur through one of several mechanisms including increased repair or proliferation of the beta-cells and stimulation of insulin secretion Adeneye and Agbaje (2008). This mechanism of action depicted the underlying principle through which the ethanolic bark extracts of Khaya senegalensis reduced blood glucose concentration.
Haematological parameters are usually associated with heath challenges and are of diagnostic importance in clinical assessment of the state of health of a patient. Moreover, indices considered in this experiment were packed cell volume, haemoglobin, mean corpuscular haemoglobin concentration (MCHC), total red blood cell and white blood cell count. There was significant decrease $(\mathrm{p}<0.05)$ in packed cell volume, haemoglobin and mean corpuscular haemoglobin concentration, in the extract treated groups when compared to non-diabetic control groups D1 and D2 but with an attendant increase $(p<0.05)$ when compared with diabetic control. The diabetic orthodox group showed a similar decrease $(\mathrm{p}<0.05)$ with no significance when compared with the non-diabetic control and diabetic control respectively while the diabetic control group showed a significant decrease at $p<0.05$ in comparison with the non-diabetic control group. Total white blood cell (WBC) was significantly increased $(p<0.05)$ in diabetic control rats compared with the non-diabetic control rats while the level of WBC in extract treated groups significantly decreased $(\mathrm{p}<0.05)$ when compared to diabetic control rats with an attendant increase $(\mathrm{p}<0.05)$ when compared with the non-diabetic control (Fig. 1-9; Table $1)$.

Table.1 Results of quantitative phytochemical screening of Khaya senegalensis bark extract

\section{Phytochemicals}

Glycoside

Steriods

Antraquinones

Cardenolides

\section{Percentage composition (\%)}

57.50

11.05

0,48 
Fig.1 Graph showing initial and final weights of rats induced with diabetes, orthodox and extract treated Albino Wistar rats

\section{BODY WEIGHT INDICES}

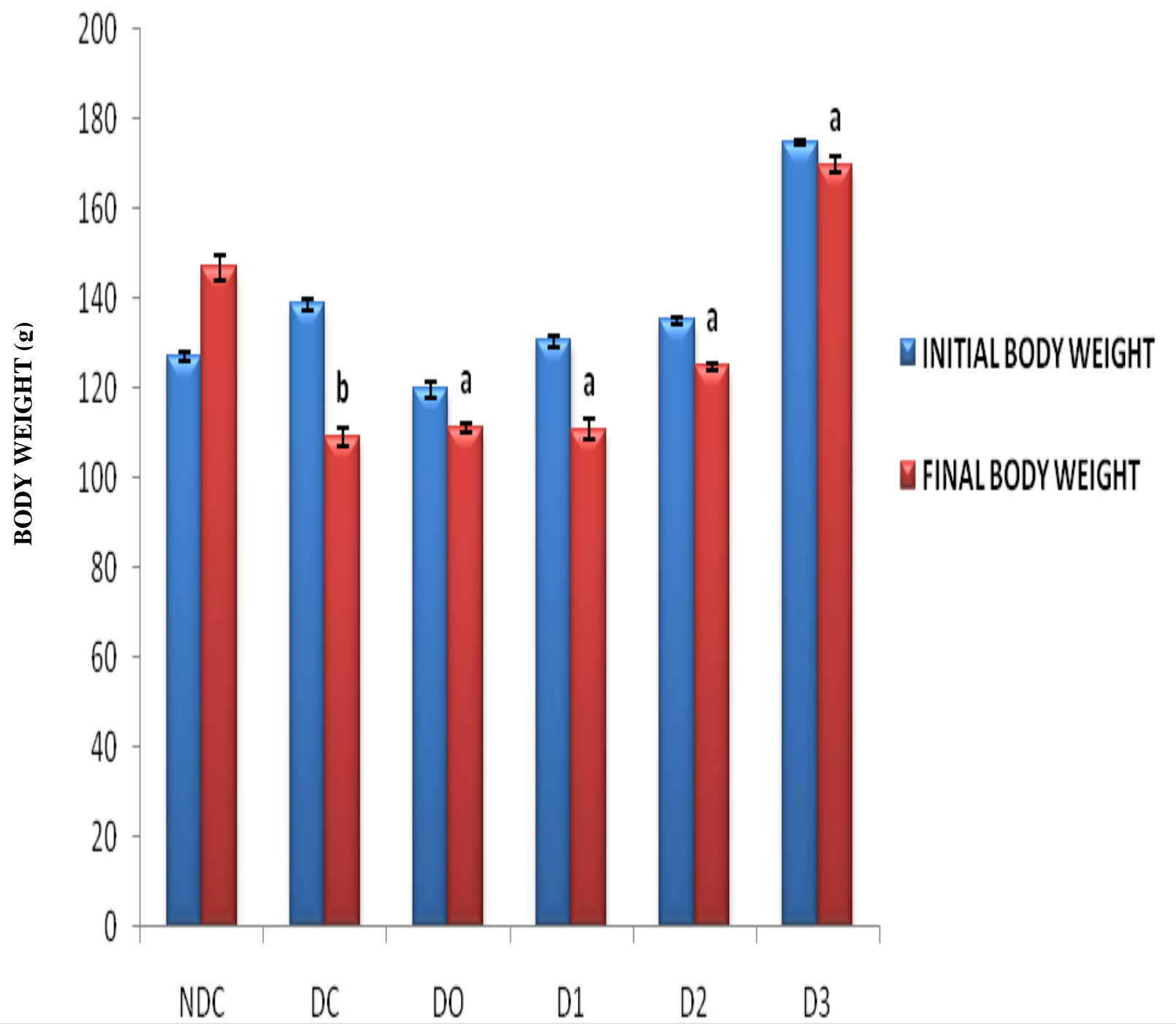

Values expressed in MEAN \pm SEM of 10 determinations.

KEY:

NDC: Positive control.

DC: Negative control.

DO: Negative control $+1 \mathrm{ml}$ of insulin.

D1: Negative control $+1 \mathrm{ml}$ of $100 \mathrm{mg} / \mathrm{dl}$ of ethanolic stem-bark extract of K.senegalensis.

D2: Negative control $+1 \mathrm{ml}$ of $200 \mathrm{mg} / \mathrm{dl}$ of ethanolic stem-bark extract of K.senegalensis.

D3: Negative control $+1 \mathrm{ml}$ of $400 \mathrm{mg} / \mathrm{dl}$ of ethanolic stem-bark extract of K.senegalensis.

a: Significant increase at $\mathrm{P}<0.05$.

b: Significant decrease at $\mathrm{P}<0.05$. 
Fig.2 Graph showing blood glucose level at day 0, day 3 and day 7 of administration of ethanolic stem-bark extract of Khaya senegalensis in alloxan-induced Albino Wistar rats

\section{BLOOD GLUCOSEASSAY}

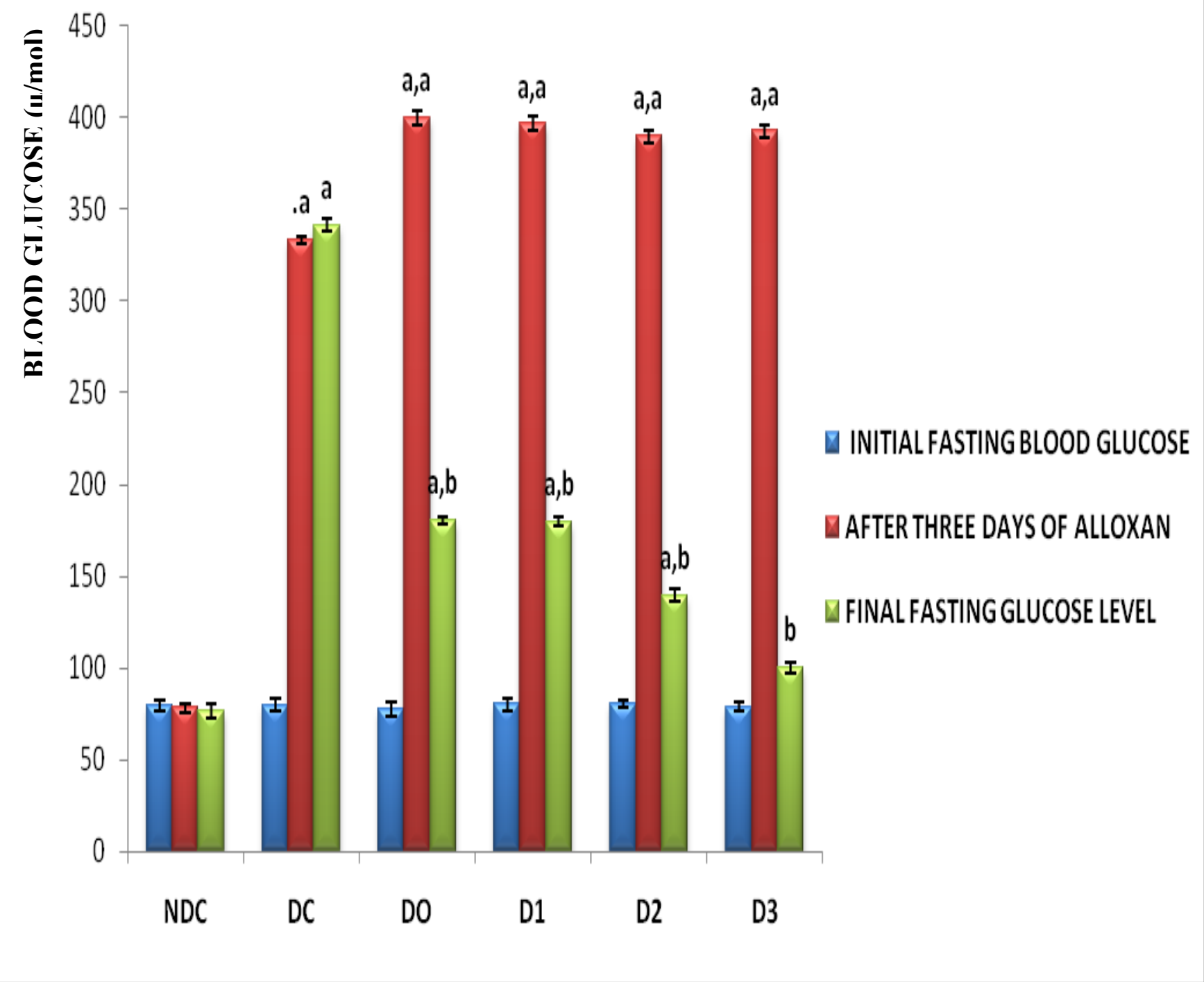

Values expressed in MEAN \pm SEM of 10 determinations.

KEY:

NDC: Positive control.

DC: Negative control.

DO: Negative control $+1 \mathrm{ml}$ of insulin.

D1: Negative control $+1 \mathrm{ml}$ of $100 \mathrm{mg} / \mathrm{dl}$ of ethanolic stem-bark extract of K.senegalensis.

D2: Negative control $+1 \mathrm{ml}$ of $200 \mathrm{mg} / \mathrm{dl}$ of ethanolic stem-bark extract of K.senegalensis.

D3: Negative control $+1 \mathrm{ml}$ of $400 \mathrm{mg} / \mathrm{dl}$ of ethanolic stem-bark extract of K.senegalensis.

a: Significant increase at $\mathrm{P}<0.05$.

b: Significant decrease at $\mathrm{P}<0.05$ 
Fig.3 Graph showing haemoglobin, packed cell volume and red blood cell indices of ethanolic stem-bark extract of Khaya Senegalensis in alloxan-induced diabetic rats

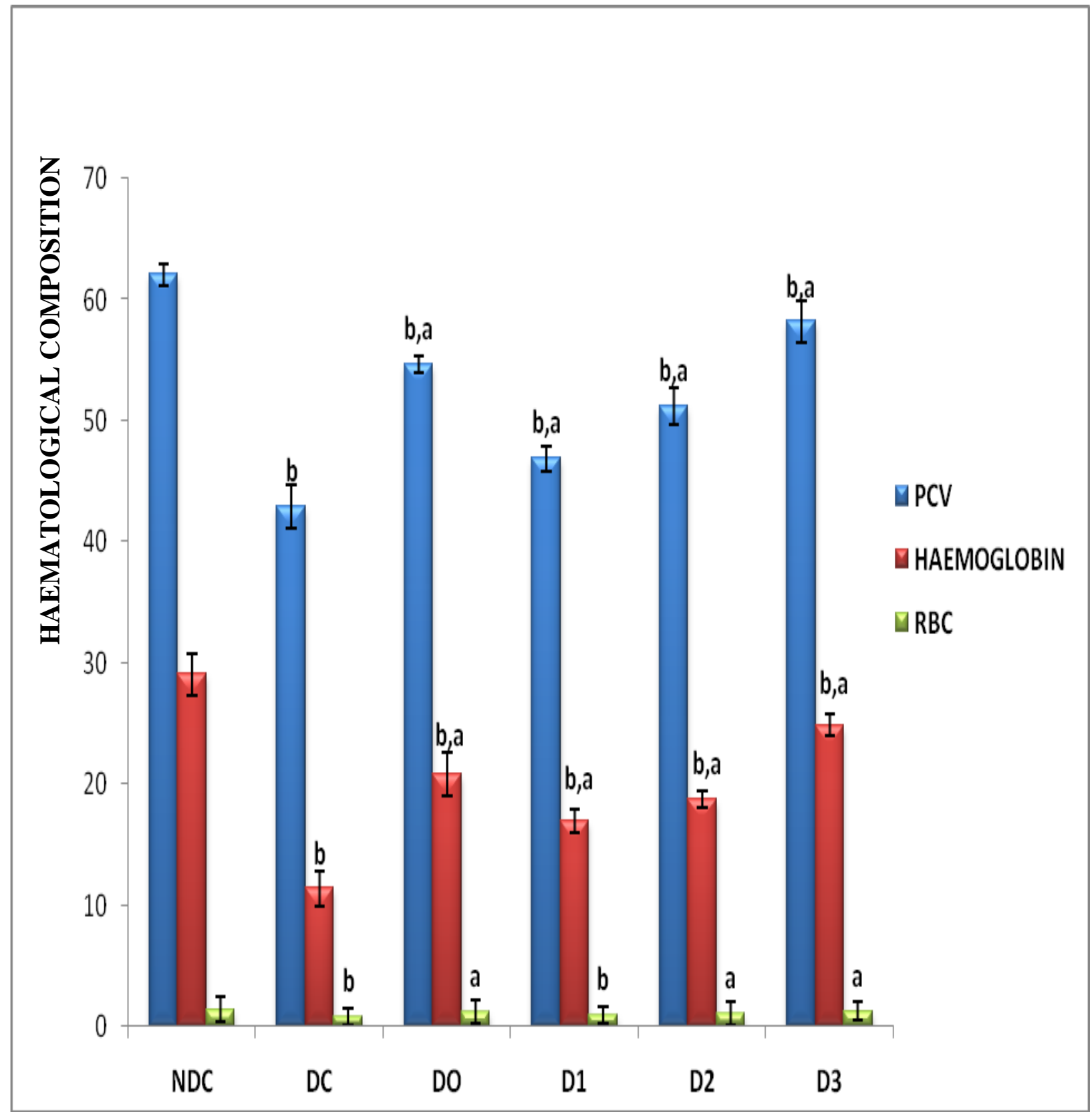

Values expressed in MEAN \pm SEM of 10 determinations.

KEY:

NDC: Positive control.

DC: Negative control.

DO: Negative control $+1 \mathrm{ml}$ of insulin.

D1: Negative control $+1 \mathrm{ml}$ of $100 \mathrm{mg} / \mathrm{dl}$ of ethanolic stem-bark extract of K.senegalensis.

D2: Negative control $+1 \mathrm{ml}$ of $200 \mathrm{mg} / \mathrm{dl}$ of ethanolic stem-bark extract of K.senegalensis.

D3: Negative control $+1 \mathrm{ml}$ of $400 \mathrm{mg} / \mathrm{dl}$ of ethanolic stem-bark extract of K.senegalensis.

a: Significant increase at $\mathrm{P}<0.05$.

b: Significant decrease at $\mathrm{P}<0.05$. 
Fig.4 Graph showing haemoglobin, packed cell volume and red blood cell indices of ethanolic stem-bark extract of Khaya Senegalensis in alloxan-induced diabetic rats

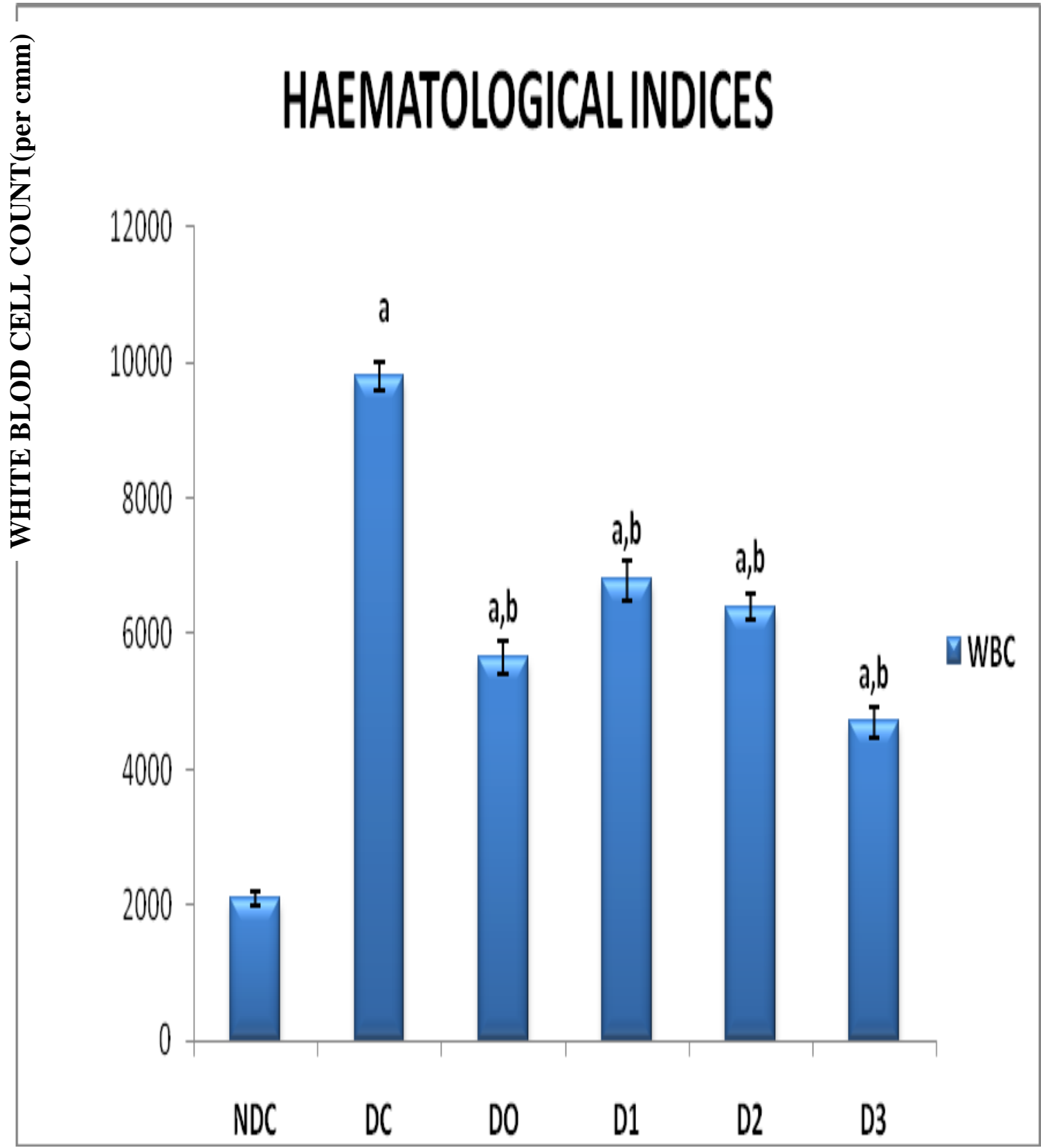

Values expressed in MEAN \pm SEM of 10 determinations.

KEY:

NDC: Positive control.

DC: Negative control.

DO: Negative control $+1 \mathrm{ml}$ of insulin.

D1: Negative control $+1 \mathrm{ml}$ of $100 \mathrm{mg} / \mathrm{dl}$ of ethanolic stem-bark extract of K.senegalensis.

D2: Negative control $+1 \mathrm{ml}$ of $200 \mathrm{mg} / \mathrm{dl}$ of ethanolic stem-bark extract of K.senegalensis.

D3: Negative control $+1 \mathrm{ml}$ of $400 \mathrm{mg} / \mathrm{dl}$ of ethanolic stem-bark extract of K.senegalensis.

a: Significant increase at $\mathrm{p}<0.05$.

b: Significant decrease at $\mathrm{p}<0.05$. 
Fig.5 Graph showing haemoglobin, packed cell volume and red blood cell indices of ethanolic stem-bark extract of Khaya Senegalensis in alloxan-induced diabetic rats

\section{HAEMATOLOGICALINDICES}

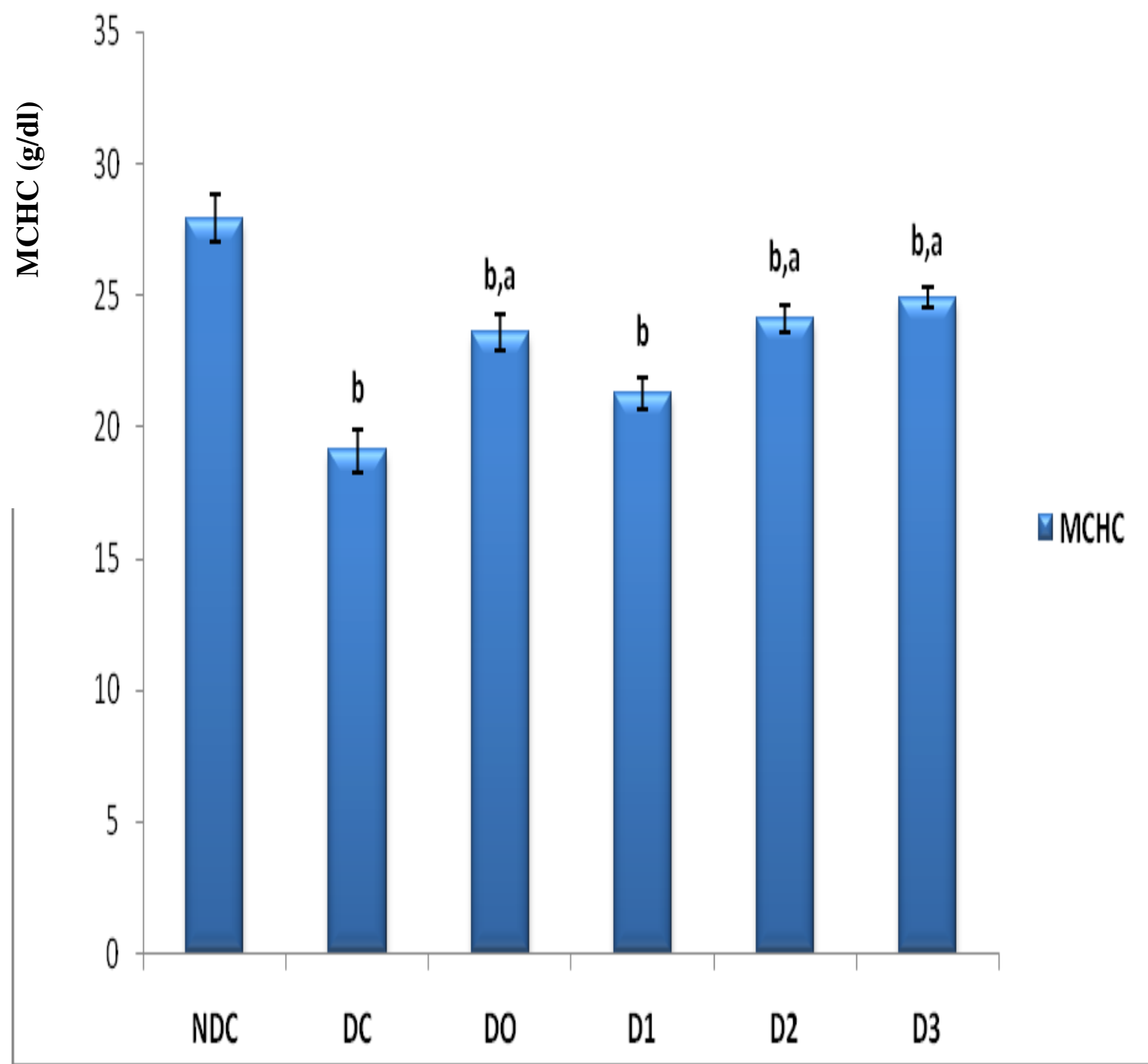

Values expressed in MEAN \pm SEM of 10 determinations.

KEY:

NDC: Positive control.

DC: Negative control.

DO: Negative control $+1 \mathrm{ml}$ of insulin.

D1: Negative control $+1 \mathrm{ml}$ of $100 \mathrm{mg} / \mathrm{dl}$ of ethanolic stem-bark extract of K.senegalensis.

D2: Negative control $+1 \mathrm{ml}$ of $200 \mathrm{mg} / \mathrm{dl}$ of ethanolic stem-bark extract of K.senegalensis.

D3: Negative control $+1 \mathrm{ml}$ of $400 \mathrm{mg} / \mathrm{dl}$ of ethanolic stem-bark extract of K.senegalensis.

a: Significant increase at $\mathrm{p}<0.05$.

b: Significant decrease at $\mathrm{p}<0.05$. 
Fig.6 Graph showing the lipid profile levels of rats induced with diabetes, orthodox and extract treated Albino Wistar rats

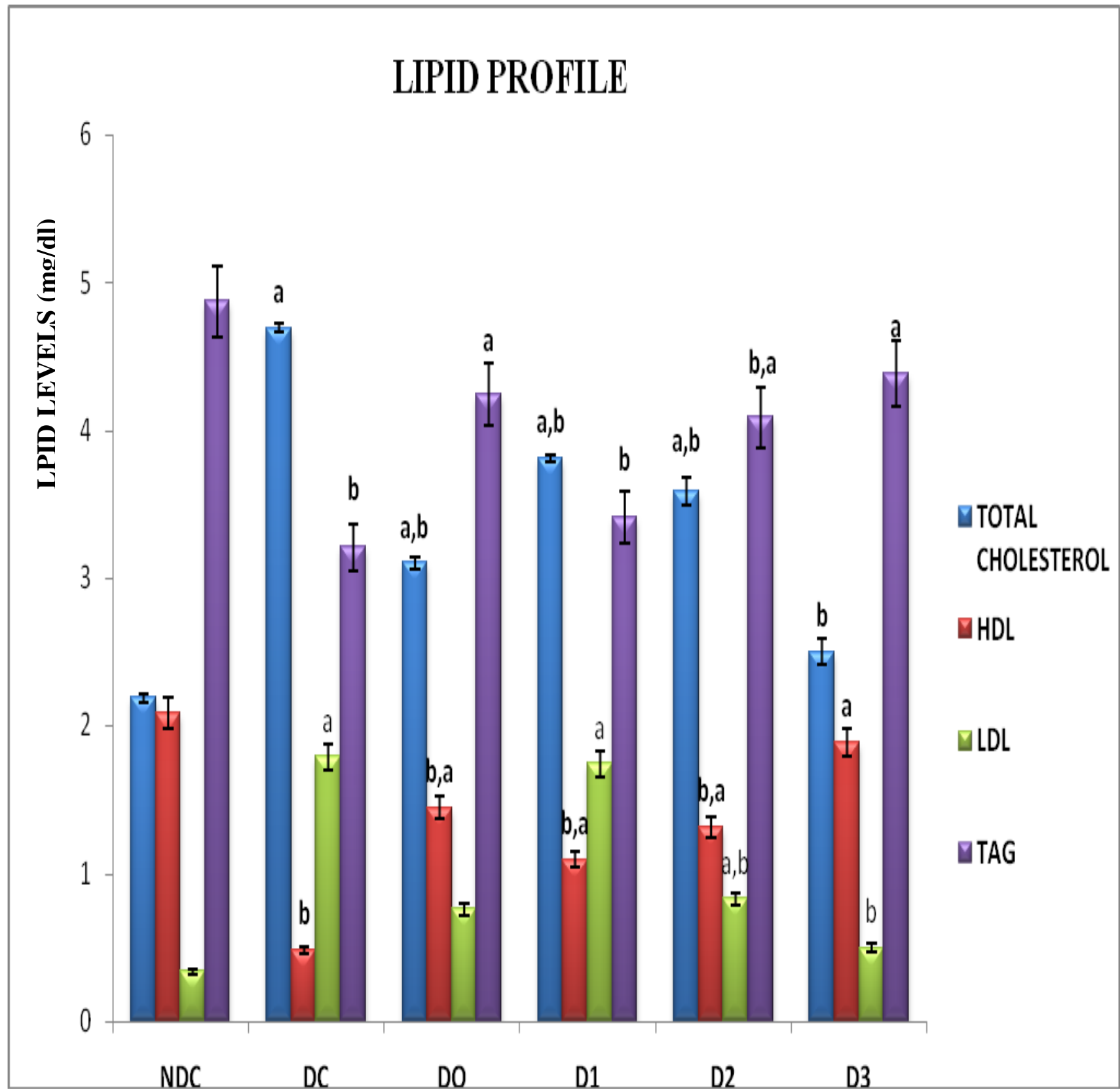

Values expressed in MEAN \pm SEM of 10 determinations.

KEY:

NDC: Positive control.

DC: Negative control.

DO: Negative control $+1 \mathrm{ml}$ of insulin.

D1: Negative control $+1 \mathrm{ml}$ of $100 \mathrm{mg} / \mathrm{dl}$ of ethanolic stem-bark extract of $K$. senegalensis.

D2: Negative control $+1 \mathrm{ml}$ of $200 \mathrm{mg} / \mathrm{dl}$ of ethanolic stem-bark extract of $K$. senegalensis.

D3: Negative control $+1 \mathrm{ml}$ of $400 \mathrm{mg} / \mathrm{dl}$ of ethanolic stem-bark extract of $K$. senegalensis.

a: Significant increase at $\mathrm{p}<0.05$.

b: Significant decrease at $\mathrm{p}<0.05$. 
Fig.7 Graph showing the serum enzyme levels of rats induced with diabetes, orthodox and extract treated Albino Wistar rats

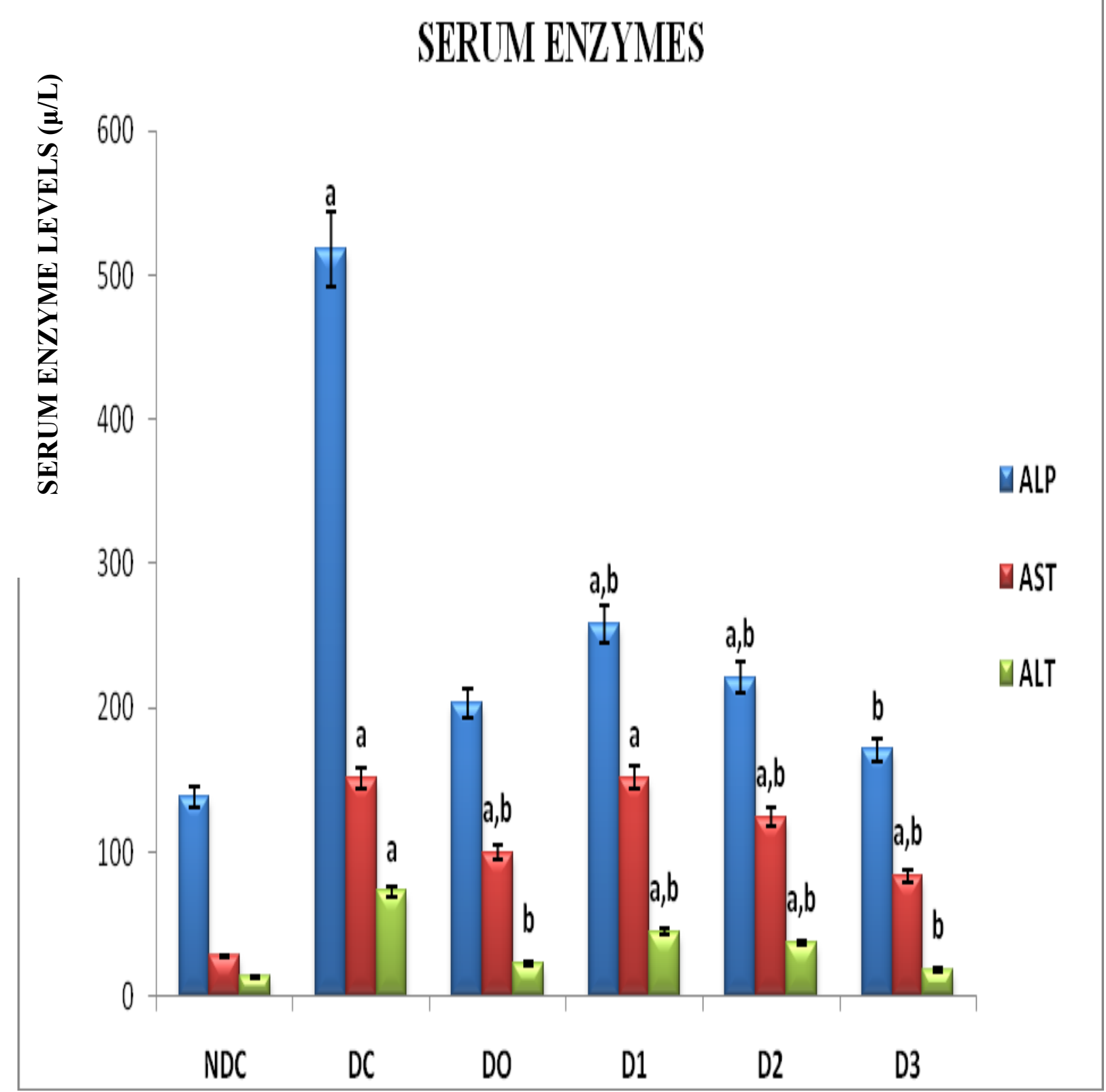

Values expressed in MEAN \pm SEM of 10 determinations.

KEY:

NDC: Positive control.

DC: Negative control.

DO: Negative control $+1 \mathrm{ml}$ of insulin.

D1: Negative control $+1 \mathrm{ml}$ of $100 \mathrm{mg} / \mathrm{dl}$ of ethanolic stem-bark extract of K.senegalensis.

D2: Negative control $+1 \mathrm{ml}$ of $200 \mathrm{mg} / \mathrm{dl}$ of ethanolic stem-bark extract of K.senegalensis.

D3: Negative control $+1 \mathrm{ml}$ of $400 \mathrm{mg} / \mathrm{dl}$ of ethanolic stem-bark extract of K.senegalensis.

a: Significant increase at $\mathrm{P}<0.05$.

b: Significant decrease at $\mathrm{P}<0.05$. 
Fig.8 Graph showing albumin and urea levels of rats induced with diabetes, orthodox and extract treated Albino Wistar rats

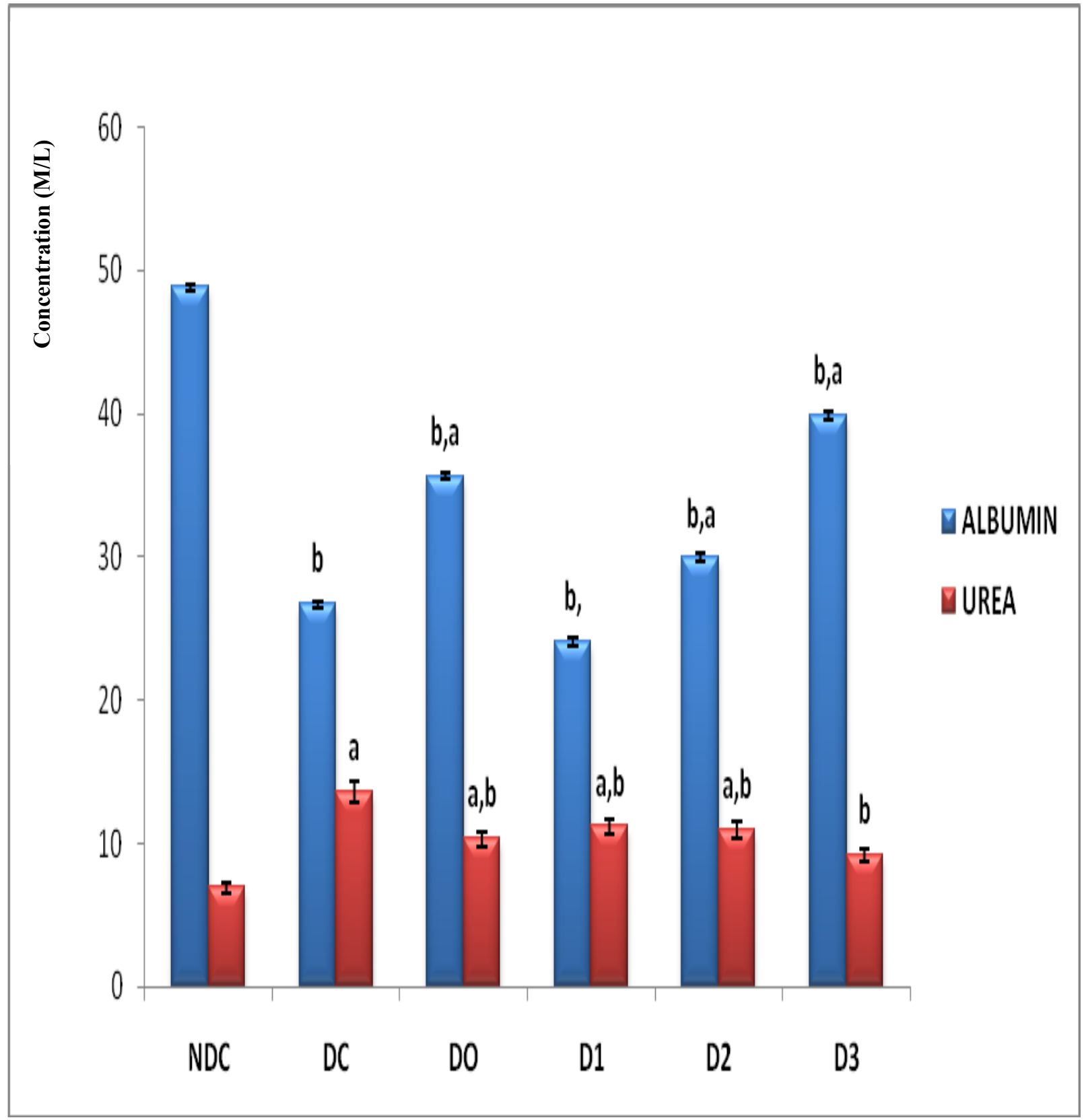

Values expressed in MEAN \pm SEM of 10 determinations.

KEY:

NDC: Positive control.

DC: Negative control.

DO: Negative control $+1 \mathrm{ml}$ of insulin.

D1: Negative control $+1 \mathrm{ml}$ of $100 \mathrm{mg} / \mathrm{dl}$ of ethanolic stem-bark extract of K.senegalensis.

D2: Negative control $+1 \mathrm{ml}$ of $200 \mathrm{mg} / \mathrm{dl}$ of ethanolic stem-bark extract of K.senegalensis.

D3: Negative control $+1 \mathrm{ml}$ of $400 \mathrm{mg} / \mathrm{dl}$ of ethanolic stem-bark extract of K.senegalensis.

a: Significant increase at $\mathrm{P}<0.05$.

b: Significant decrease at $\mathrm{P}<0.05$. 
Fig.9 Graph showing total protein levels of rats induced with diabetes, orthodox, and extracts treated Albino Wistar rats

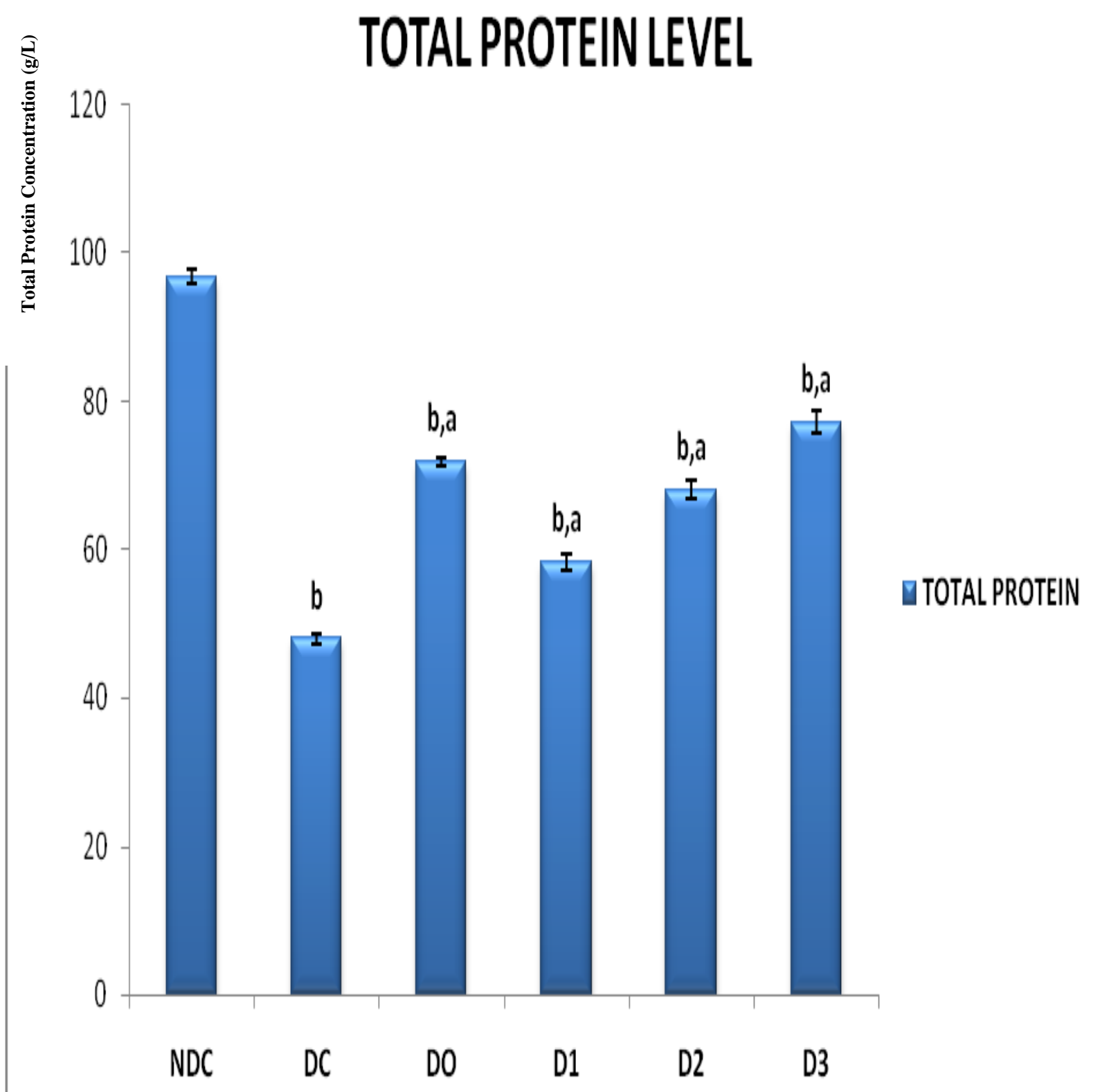

Values expressed in MEAN \pm SEM of 10 determinations.

KEY:

NDC: Positive control.

DC: Negative control.

DO: Negative control $+1 \mathrm{ml}$ of insulin.

D1: Negative control $+1 \mathrm{ml}$ of $100 \mathrm{mg} / \mathrm{dl}$ of ethanolic stem-bark extract of K.senegalensis.

D2: Negative control $+1 \mathrm{ml}$ of $200 \mathrm{mg} / \mathrm{dl}$ of ethanolic stem-bark extract of K.senegalensis.

D3: Negative control $+1 \mathrm{ml}$ of $400 \mathrm{mg} / \mathrm{dl}$ of ethanolic stem-bark extract of K.senegalensis.

a: Significant increase at $\mathrm{P}<0.05$.

b: Significant decrease at $\mathrm{P}<0.05$. 
Blood parameters are good indicators of physiological, pathological and nutritional state of an animal and changes in haematological parameters gives an insight of a pathological condition and explains the impact of therapeutic drug testing. In this study, the result of haematological studies shows that Khaya senegalensis have proportionally increasing effect on haematological parameters apart from WBC.

The lipid profile obtained in this study revealed a minimal increase in total cholesterol and low density lipoprotein (LDL) in the extract treated groups when compared with the non-diabetic control but with an attendant significant decrease when compared with diabetic control group. Diabetic control rats showed marked increase $(\mathrm{p}<0.05)$ in cholesterol and decrease in HDL levels when compared to non-diabetic control. High density lipoprotein (HDL) and total glycerides increased significantly $(\mathrm{p}<0.05)$ in the extract treated group in comparison to the diabetic control rat but a minimal decrease was observed when compared with the nondiabetic rats, while diabetic control showed a significant decrease $(\mathrm{p}<0.05)$ in HDL and total glycerides levels in comparison with non-diabetic control rats; Fernendes et al., (2010) reported a similar decrease. This result is in conformity with the fact that diabetesinduced hyperlipidemia is due to excess of fat from the adipose tissue during the underutilization of glucose as hypothesized by Nimenibo-uadia, (2003).

The hepatic serum enzymes are valuable tool in clinical diagnosis and it provides information on the effect and nature of pathological damage to tissues (Daisy and Saipriya, 2012). Furthermore, Alanine transaminase (ALT), aspartate transaminase (AST), and alkaline phosphatase (ALP) are biomarkers which are often used to assess the integrity of the plasma membrane and tissues after being exposed to certain pharmacological agents (Rathod et al., 2009). Results obtained in this study revealed a significant decrease $(\mathrm{p}<0.05)$ in the activity of ALT and ALP in the extract treated groups when compared with the diabetic control rats but with a significant increase $(p<0.05)$ when compared to the diabetic control; the ability of $K$. senegalensis to revamp diabetic condition in animals by decreasing the levels of hepatic serum enzymes suggests its hepato-cellular protective function which can be attributed to its antioxidant function as stated by Lompo et al., (2007). Hepatic serum enzymes were significantly elevated in the diabetic control group when compared with non-diabetic control rats while diabetic orthodox group revealed a significant decrease $(\mathrm{p}<0.05)$ in comparison with the diabetic control group. This report is consistent with the report of Abolfathi et al., (2012) who reported that the elevation in markers of liver injury such as ALT, AST, and ALP indicate hepatocyte damage in experimental diabetes and an increase in the level of these enzymes in diabetes may be as a result of leaking out of these enzymes from the compromised tissue into the blood stream (Concepcion et al., 1993). Total protein and albumin concentrations in the extract treated group were significantly decreased when compared with the non-diabetic control but with an attendant increase when compared with diabetic control group. Diabetic control rats also showed significant decrease in total protein when compared to non-diabetic control rats. There was a significant increase in the urea level $(\mathrm{p}<0.05)$ in the extract treated groups when compared to non-diabetic control but with attendant decrease when compared with diabetic control.

The present study has demonstrated that ethanolic stem-bark extract of Khaya senegalensis possesses anti-hyperglycaemic effect which is in turn attributable to the 
various biologically active metabolites detected during the phytochemical screening. It is therefore apparent that the anti-diabetic potency of Khaya senegalensis will prove to be an effective treatment of type I diabetes mellitus.

\section{Competing Interest}

The authors affirm that there is no conflict of interest in the publication of this article.

\section{Ethical approval}

All authors hereby declare that research has been determined exempt from review by the University animal research or ethics review committee and that the principles of laboratory animal's care were strictly observed.

\section{References}

Abebe, D., Debella, A. and Urga, K. (2003). Illustrative checklist: Medicinal plants and other useful plants of Ethiopia. EHNRI, Camerapix Publisher International, Nairobi, Kenya, P. 188194.

Adeneye, A.A. and Agbaje, E.O. (2008). Pharmacological evaluation of oral hypoglycaemic and antidiabetic effect of fresh leaves extract of Morinda lucida in normal and alloxan-induced diabetic rats. Afr.J. Biomed.Res., 11: 65-71.

Andrade-Cetto, A. and Heinrich, M. (2005). Mexican plants with hypoglycemic effect used in the treatment of diabetes. J Ethnopharmacol., 99(3), 325-348.

Assubaie, N.F. and El-Garawany, M.M. (2004). Evaluation of some important chemical constituents of Momordica charantia cultivated in Hofuf Saudi Arabia. J. Biol. Sci, 4, 628-630.
Baker, R. and Silverton, T. (2003). Blood: Principles \& Practice of Hematology. Lippincott William \& Wilkins, 4, 183189.

Bassey, M., Udagawa, N., Fukasawa, K., Hiraoka, B.Y. and Mogi, M. (1946).'Inorganic pyrophosphatase activity of purified bovine pulp alkaline phosphatase at physiological $\mathrm{pH}^{\prime} \mathrm{J}$. Dent. Res. 65 (2): 125-7.

Chattopadhyay, R.R. (1996). Possible mechanism of anti-hyperglycemic effect of Azadirachta indica leaf extract. Part IV. General Pharmacology: The Vascular System 27(3), 431-434.

Concepcion, N.M., Pilar, M.M., Martin, A., Jimenez, J. and pilar U.M. (1993). Free radical scavenger and antihepatoxic activity of Rosmarinustomentosus. PlantaMedica, 59:312-314

Falodun, A. (2010). Herbal medicine in Africa - Distribution, standardization and prospects. Res J. Phytochem., 4, $154-161$

Gill, L.S. (1992). Ethnomedical Uses of Plants in Nigeria. Uniben Press, Benin City, 15-65.

Ignacimuthu, S., Ayyanar, M. and Sivaraman, K.S. (2006). Ethnobotanical investigations among tribes in Madurai district of Tamil Nadu (India). J. Ethnobiol Ethnomed., 2, 25.

Kamalakkannan, N., Prince, P.S. (2006). Anti-hyperglycemic and antioxidant effect of rutin, and polyphenolic flavonoid in streptozotocin-induced diabetic Wistar rats. Basic Clin Pharmacol Toxicol., 98(1), 97-103.

Kolawole, O.T., Abiona, F.E., Kolawole, S.O., Ayankunle, A.A. and Olaniran, O.I. (2011). Effect of Momordica charantia fruit extract on normal and alloxan-diabetic rats. Int J Pharmacol., 7(4), 532-535.

Kumar, Vinay, F., Nelson, A., Abul, K., Cotran, R.S. and Stanley, L. (2005). 
Robbins and cotran Pathologic Basis of Diseases $\left(7^{\text {th }}\right.$ ed.). Philadelphia Pa.: Saunders. Pp. 1194-1195.

Lompo, M., Dubois, J. and Guissou, I.P. (2007.) In Vitro Preliminary Study of Free Radical Scavenging Activity of Extracts from Khaya senegalensis A. Juss. Journal of Biological Sciences, 7, 677-680

Maydell, H.J. (1986). Trees and Shrubs of Sahel-Their Characteristics and Uses. Gesdtschaft, Fur, Germany, 105-110.

Nagappa, A.N., Thakurdesai, P.A., Rao, N.V. and Singh, J. (2003). Antidiabetic activity of Terminalia catappa Linn fruits. J Ethnopharmacol., 88, 45-50.

NIH. (2008). Guide for the use of laboratory animals. DHHS, PHS, NIH Publication No. 85-23.

Nimenibo-uadia, R. (2003). Effect of aqueous extract of canavaliaensiformis seeds on hyperlipidemic and hyperketoanaemia in alloxan-induced diabetic rats. Biokemistri, 157-15.

Odebiyi, A. and Sofowora, A.E. (1978). Phtochemmical Screenng of Nigerian Medicinal Plants. Part III. Lloydia. 41:234-246.

Pavana, P., Sethupathy, S. and Manoharan, S. (2008). Protective role of Tephrosia purpurea

Petit, S. (2003) Parklands with fodder trees: a Fulße response to environmental and social changes. Applied Geography, 23, 205-225.

Reitman, F.J. and Frankel, E.T. (1957). "Purification and Characterization of aspartate aminotransferase from the halophile archaebacterium Haloferaxmediterranei", Biochem J. 278(1); 149-54.

Ribnicky, D.M., Poulev, A., Watford, M., Cefalu, W.T. and Raskin, I. (2006). Antihyperglycemic activity of Tarralin, an ethanolic extract of Artemisia dracunculus L. Phytomedicine, 13(8), 550-557.

Shoback, edited by David, G.g., Doores. (2011). Greenspson's basic \& Clinical endocrinology $\left(9^{\text {th }}\right.$ ed.). New York; McGraw-Hil Medical. pp. 213 Chapter 17. ISBN 978-1-4020-6431-2.

Suryawanshi, N.P., Bhutey, A.K., Nagdeote, A.N., and Jadhav, A.A, and Monookar, G.S. (2006). Study of lipid peroxide and lipid profile in diabetes mellitus. Indian jour. Of clini. Biochem., (1): 126-130.

White, J.R., Davis, S.N., Cooppan, R., Davidson, M.B., Mulcahy, K., Manko, G.A. and Nelinson, D. (2003). Clarifying the role of insulin in type 2 diabetes management. Clinical Diabetes 21, 14-21.

Wild, S., Roglic, G., Green, A., Sicree, R., and King, H. (2004). Global prevalence of diabetes estimates for the year 2000 and projections for 2030. Diabetes Care, 27, 1047-1053.

Wright, A. and Plummer, C. (1974). "A finestructure genetic and Chemical study of the enzyme Alkaline phosphatase of E. Coli. I. Purification and characterization of alkaline phosphatase: Biochem. Biophys. Acta 38: 470-83.

\section{How to cite this article:}

Ukpanukpong, R.U., J.O. Ajani, W.A. Omang, R.I. Oplekwu, M.A. Adejorin, M.U. Eteng and Eyong, E.U. 2018. Antidiabetic and Antilipidemic Effect of Khaya senegalensis Ethanolic Bark Extract in Alloxan Induced Diabetic Wistar Rats. Int.J.Curr.Microbiol.App.Sci. 7(08): 291-307. doi: https://doi.org/10.20546/ijcmas.2018.708.034 